\title{
A new hybrid pressure-coring system for the drilling vessel Chikyu
}

\author{
Y. Kubo ${ }^{1}$, Y. Mizuguchi ${ }^{1, *}$, F. Inagaki ${ }^{2,3}$, and K. Yamamoto $^{4}$ \\ ${ }^{1}$ Center for Deep-Earth Exploration (CDEX), Japan Agency for Marine-Earth Science and Technology \\ (JAMSTEC), Yokohama 236-0061, Japan \\ ${ }^{2}$ Kochi Institute for Core Sample Research, JAMSTEC, Nankoku, Kochi 783-8502, Japan \\ ${ }^{3}$ Submarine Resources Research Project, JAMSTEC, Yokosuka 237-0061, Japan \\ ${ }^{4}$ Japan Oil, Gas and Metals National Corporation, 1-2-2 Hamada, Mihama-ku, Chiba-shi, \\ Chiba 261-0025, Japan \\ *current address: Mantle Quest Japan Ltd., Shin-horidome Bldg. 5F, 2-4-3 Nihonbashi Horidome-cho, \\ Chuo-ku, Tokyo 103-0012, Japan \\ Correspondence to: Y. Kubo (kuboy@jamstec.go.jp)
}

Received: 1 November 2013 - Revised: 6 February 2014 - Accepted: 7 February 2014 - Published: 29 April 2014

\begin{abstract}
Retrieving core samples without releasing the in situ hydrostatic pressure during core recovery is one of the many technical challenges in scientific drilling. We report here a newly developed hybrid pressurecoring system for the use on the drilling vessel Chikyu and its successful use during expeditions 906 and 802 in the Nankai Trough of Japan. The system is gas-tight and hence enables researchers to study in situ geophysical and geochemical characteristics of sediments containing gaseous components, such as methane hydrates that cannot be reliably recovered with nonpressure coring systems. In addition, pressure coring is a powerful tool, not only for scientific but also for hydrocarbon resources research.
\end{abstract}

\section{Introduction}

The general concept of pressure coring as a technique has long been tested for scientific ocean drilling since the DeepSea Drilling Project (DSDP) in the 1980s. A pressure-coring barrel was first developed and tested for capturing methane hydrate-bearing sediments in the Blake Ridge (Kvenvolden et al., 1983). During the Ocean Drilling Program (ODP), the pressure core sampler (PCS; Pettigrew, 1992; Graber et al., 2002) was developed for the drilling vessel (D/V) JOIDES Resolution. Using the PCS, gas-rich or methane hydratebearing sediments were successfully retrieved from the western Pacific coast during ODP legs 164 (Dickens et al., 1997, 2000; Paull et al., 2000), 201 (Dickens et al., 2003) and 204 (Shipboard Scientific Party, 2003). During ODP leg 204 at the Cascadia margin, Fugro pressure corer (FPC) and the hydrate autoclave coring equipment (HYACE) rotary corer were also deployed on the D/V JOIDES Resolution, resulting in the successful sample recovery (Shipboard Scientific
Party, 2003). During the Integrated Ocean Drilling Program (IODP), the same systems were used during expedition 311 on the JOIDES Resolution, and methane hydrate-bearing sediments were successfully recovered from 16 horizons of Hydrate Ridge on the Cascadia margin (Expedition 311 Scientists, 2005).

Besides scientific operations, pressure coring has been used for the exploration of natural hydrocarbon resources, including oil, gas and methane hydrates. For example, pressure-coring systems have been used for governmental resource survey of methane hydrates offshore of India, China and Korea using the JOIDES Resolution and other drilling vessels (Schultheiss et al., 2009). The Japan Oil, Gas and Metals National Corporation (JOGMEC) developed a pressure-temperature coring system (PTCS), and performed coring surveys for methane hydrates in the Nankai Trough of Japan (Fujii et al., 2010). The pressure-coring tools that have been developed so far are summarized in Table 1. 
Table 1. Summary of available pressure-coring technique.

\begin{tabular}{|c|c|c|c|c|}
\hline & $\begin{array}{l}\text { Drill pipe } \\
\text { diameter } \\
\text { (in) }\end{array}$ & $\begin{array}{l}\text { Core } \\
\text { OD } \\
\text { (in) }\end{array}$ & $\begin{array}{l}\text { Core } \\
\text { length } \\
(\mathrm{m})\end{array}$ & $\begin{array}{l}\text { Max. } \\
\text { pressure } \\
\text { (Mpa) }\end{array}$ \\
\hline ODP PCS & \multirow{3}{*}{5 or $51 / 2$} & 1.575 & 1 & 69 \\
\hline Fugro HYACE RC & & 2 & 1 & 21 \\
\hline Fugro FPC & & 2.125 & 1 & 25 \\
\hline JOGMEC PTCS & $65 / 8$ & 2.625 & 3.5 & 24 \\
\hline CDEX hybrid PCS & 5 or $51 / 2$ & 2 & 3.5 & 35 \\
\hline
\end{tabular}

However, prior to the current development there was no pressure-coring tool deployable through the bottom hole assembly (BHA) of the D/V Chikyu. Here we report development of a new pressure-coring system for D/V Chikyu and first offshore operations.

\section{Design and use of hybrid pressure coring system}

The newly developed hybrid pressure coring system (hybrid PCS) was designed mainly by a combined design of PCS and PTCS, with original modifications of the sealing function (Fig. 1). Similar to its predecessors, the hybrid PCS is a wireline-based hydraulically actuated pressure-coring system for 5 and $51 / 2 \mathrm{in.} \mathrm{drill} \mathrm{strings,} \mathrm{and} \mathrm{interchangeable} \mathrm{to}$ the hydraulic piston coring system (HPCS) and the extended shoe coring system (ESCS) on the Chikyu. The system can be latched in the BHA and rotates with the BHA during coring. Hence, the hybrid PCS cannot retrieve oriented cores. The maximum pressure is $\sim 35 \mathrm{MPa}(5000 \mathrm{psi})$ and the core sample of the hybrid PCS is $51 \mathrm{~mm}$ in diameter with a maximum core length of $3.5 \mathrm{~m}$.

The hybrid PCS consists of three major subassemblies: (1) the upper assembly is composed of the running and retrieving tool; (2) the middle assembly for pressure control, which includes a pressurized nitrogen reservoir; and (3) the lower assembly for the sample autoclave (Fig. 1). Two types of cutting shoes are deployable with the hybrid PCS, depending on the lithological characteristics of the target formation: one extends $10 \mathrm{~mm}$ ahead of the bit and rotates with drill pipes, while the other has $50 \mathrm{~mm}$ extension without rotation.

In practice, the hybrid PCS is lowered by wireline through the drill string to land in the BHA. The hybrid PCS is rotated using the top drive via the latch and BHA drill string. During the coring process the drilling mud pumps maintain drilling mud flow down the drill string to keep the hole open as well as to cool and lubricate the coring drill bit. Once the core has been cut and the drilling mud pumps are stopped, the retrieving tool is lowered wireline and latched to the hybrid PCS. Pulling on the wire applies a force first to the inner latch of the hybrid PCS, which then releases the inner barrel. Lifting up the retrieving tool triggers the following actions: (1) the
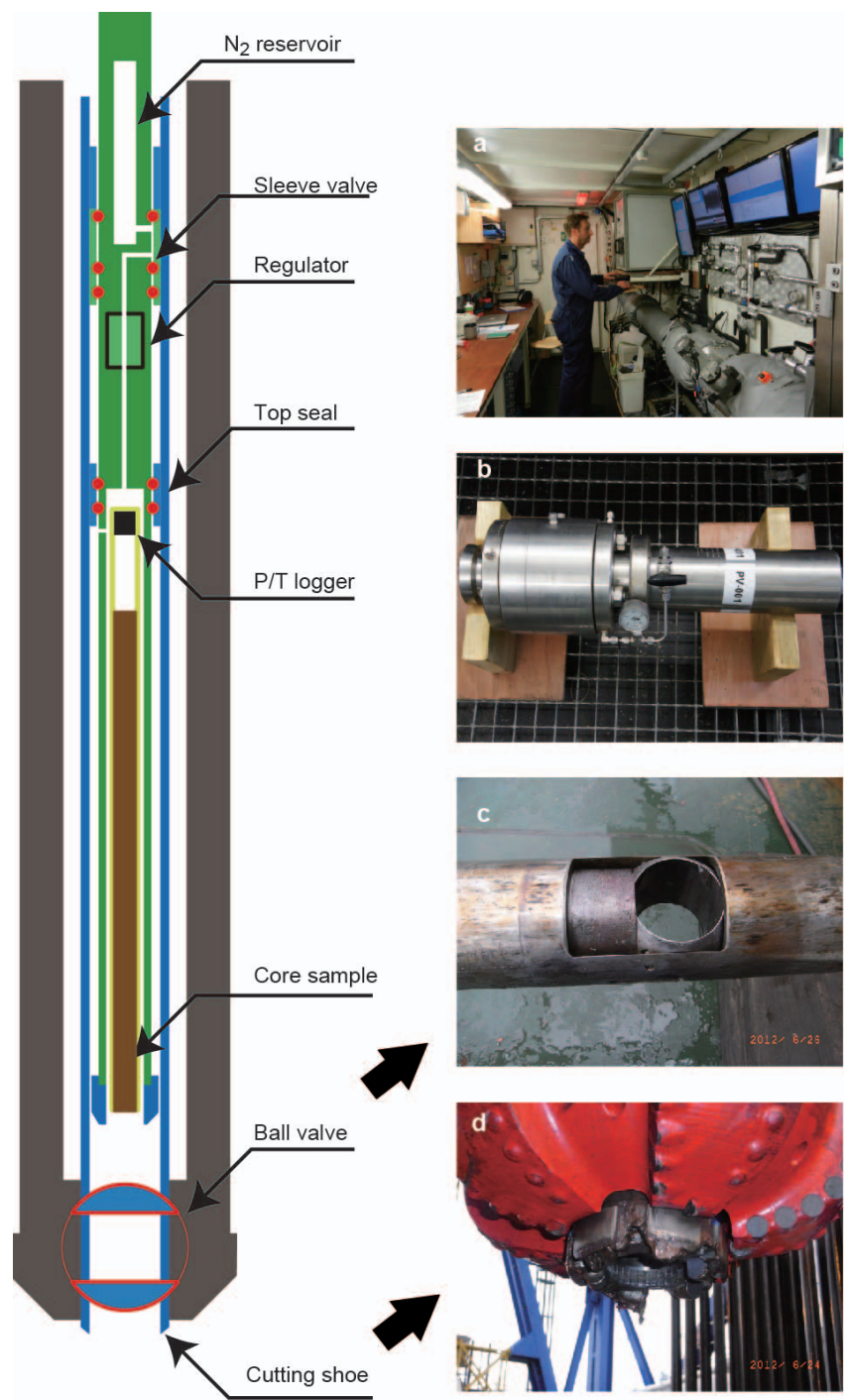

Figure 1. Schematic illustration of the hybrid pressure coring system showing the sealing mechanism by the top seal and the bottom ball valve. The autoclave is connected to the $\mathrm{N}_{2}$ reservoir that supports the pressure at a predefined value. Pictures from expedition 906 show (a) a Geotek operator and equipment in the PCATS laboratory, (b) the storage chamber for a short sample $(15 \mathrm{~cm}),(\mathbf{c})$ a closed ball valve in the hybrid PCS, and (d) the PDC drill bit with a short cutting shoe.

top seal of the autoclave is closed, (2) the lower ball valves of the autoclave are closed by spring force, (3) connection to the $\mathrm{N}_{2}$ reservoir is opened and the pressure in the autoclave is kept at a predefined pressure that has been supplied from $\mathrm{N}_{2}$ in accordance with regulator via drilling mud, and (4) the inner core barrel latch is released. These actions are completed in no more than a few seconds. The hybrid PCS can then be retrieved in the same way as with other wireline core barrels.

Once recovered on the deck, the closed inner barrel is removed from the hybrid PCS and transferred into a vertical pipe near the rotary table on the rig floor filled with 
ice (mousehole). This cools the complete assembly to prevent dissolution/melting of any gas hydrate. After cooling for approximately $30 \mathrm{~min}$, the sample chamber is connected to the Pressure Core Analysis and Transfer System (PCATS, Geotek Ltd.) for sample transfer and analysis. Pressure and temperature are recorded by the pressure-temperature logger in this autoclave system.

\section{Onboard sample processing and analysis}

The pressurized core is immediately transferred to the PCATS after cooling in the mousehole. The PCATS is housed in a three $20 \mathrm{ft}$ container-based laboratory accepting up to $3.5 \mathrm{~m}$ long core. The core is transferred from the hybrid PCS to the PCATS pressure chamber using a linear manipulator and a rotator system (Schultheiss et al., 2009). During transfer of the pressurized core, nondestructive measurements of physical properties can be simultaneously acquired through the aluminum chamber, which includes X-ray CT imaging, gamma-ray and $P$-wave velocity measurements. Using all the data, especially the X-ray image, the core can be cut into subsections at selected positions. These subsections are stored in short pressurized sample chambers for postcruise analysis, or depressurized for further analysis and sampling in the onboard laboratory. Controlled depressurization provides an accurate volume measurement, and subsampling of gas from the sectioned sediment sample allows for accurate assessments of the volume and concentration of gas hydrate in the formation sampled.

\section{Expedition 906}

The hybrid PCS was first used on the Chikyu during expedition 906 from 26 to 28 June 2012 at the Kumano mud volcano no. 5 (hereafter KMV\#5), which is one of the most active submarine mud volcanoes in the Nankai Trough (Kuramoto et al., 2001; Tsunogai et al., 2012). Site C9004 is located on the summit of KMV\#5 $\left(3367.581^{\prime} \mathrm{N}\right.$, $13656.8085^{\prime} \mathrm{E} ; 1986.7 \mathrm{~m}$ in water depth), which was previously drilled with HPCS at hole C9004A down to $20 \mathrm{~m}$ below the seafloor (m b.s.f.) during the Chikyu expedition 903 in 2009. Based on onboard observations using an infrared thermo-view camera and X-ray CT scan, it was confirmed that HPCS cores at hole C9004A contained methane hydrates and breccia in the mud almost throughout the core, requiring retrieval of intact core samples to scientifically investigate hydrocarbons and other gaseous components such as hydrogen.

During expedition 906, we extended the drilling depth to $\sim 200 \mathrm{~m}$ b.s.f. at hole C9004B by a combined use of HPCS, hybrid PCS and ESCS. A total of 11 cores were collected from hole C9004B, in which hybrid PCS was first tested at 4 selected depths (Table 2). Four coring operations of hybrid PCS at hole C9004B were trial-and-error processes to fix

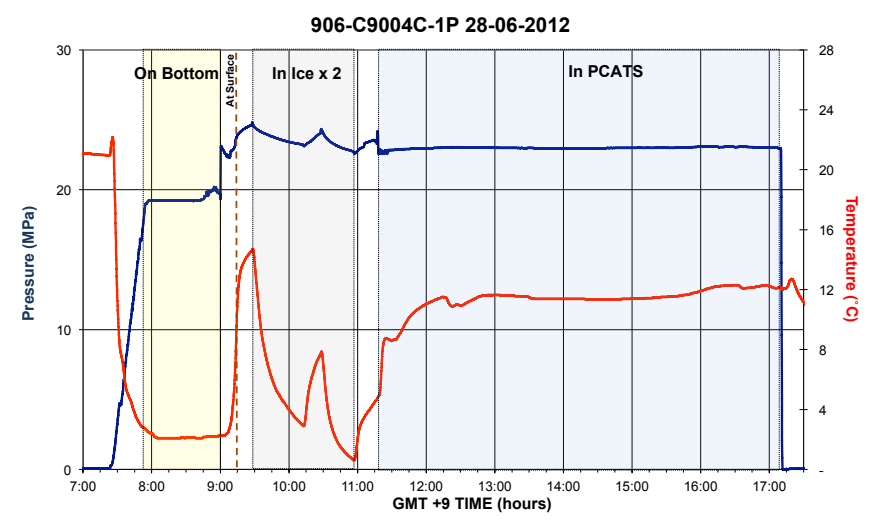

Figure 2. Pressure and temperature log from core C9004C-1 showing that the pressure in the autoclave was kept higher than the in situ pressure through retrieval, onboard handling and analysis.

and/or adjust unexpected mechanical problems on the system.

The first trial of the hybrid PCS core (C9004B-3P) resulted in no recovery due to a sealing failure and an unpressurized chamber. The second core C9004B-5P was sealed at $18 \mathrm{MPa}$, which was slightly lower than the hydrostatic pressure at the coring depth. The rig floor handling of the core, including cooling in the mousehole, took approximately $2 \mathrm{~h}$, during which the core was outside the methane hydrate stability field for $7 \mathrm{~min}$. Observations with PCATS showed that the recovered core sample was small in volume and heavily disturbed; therefore, the core was depressurized onboard. The third core C9004B-7P was also small in volume and disturbed, and did not seal completely until very close to the rig floor. A small increase in pressure after sealing was observed, possibly due to dissolution of methane hydrates. The fourth core C9004B-9P was successfully sealed at $16 \mathrm{MPa}$, indicating the autoclave and ball valve system worked properly near the sea floor. However, it was found to be an empty core barrel. An HPCS core from the nearby depth intervals suggested that the poor core recovery was due to breccia in the soft, muddy matrix.

After reaching $203.5 \mathrm{~m}$ b.s.f. at hole C9004B, we drilled a new hole, C9004C, to test the hybrid PCS near the seafloor. The fifth core, C9004C-1P, was sampled by jetting in from the mudline to $6.5 \mathrm{~m}$ b.s.f. The pressure sensor deployed in the hybrid PCS indicated that the autoclave chamber successfully sealed at $3 \mathrm{MPa}$ higher than the in situ pressure (23 MPa, Fig. 2). Observations using a X-ray CT scan from PCATS revealed an approximately $70 \mathrm{~cm}$ long sediment core containing veins filled with methane hydrate and mud clast in a soft mud matrix in the autoclave chamber (Fig. 3). The core was cut into eight sections. Four short sections were transferred into $15 \mathrm{~cm}$ long aluminum storage chambers and stored at $4{ }^{\circ} \mathrm{C}$ for shore-based analyses (Fig. 1b). The remaining three sections and one core catcher sample were used for 
Table 2. Coring summary of expedition $906 . \mathrm{H}$ : hydraulic piston coring system, X: extended-shoe coring system, P/T: hybrid PCS with short extended shoe, P/X: hybrid PCS with long extended shoe.

\begin{tabular}{|c|c|c|c|c|c|c|c|c|c|}
\hline Core & Hole & Type & $\begin{array}{r}\text { Top depth } \\
\text { (m b.s.f.) }\end{array}$ & $\begin{array}{r}\text { Bottom depth } \\
\text { (m b.s.f.) }\end{array}$ & $\begin{array}{l}\text { Advance } \\
\text { (m) }\end{array}$ & $\begin{array}{l}\text { Initial core } \\
\text { length }(\mathrm{m})\end{array}$ & $\begin{array}{r}\text { Initial recovery } \\
(\%)\end{array}$ & $\begin{array}{r}\text { Pressure } \\
(\mathrm{MPa})\end{array}$ & Remarks \\
\hline 1 & B & $\mathrm{H}$ & 0.0 & 4.0 & 4.0 & 9.68 & 242.0 & - & $\begin{array}{l}\text { Highly expanded, un- } \\
\text { consolidated silty clay } \\
\text { with pebbles. Mudline } \\
\text { was determined after } \\
\text { X-ray CT scan. }\end{array}$ \\
\hline 2 & B & $\mathrm{H}$ & 14.5 & 22.2 & 7.7 & 7.72 & 100.3 & - & $\begin{array}{l}\text { Partial penetration. } \\
\text { Highly expanded and } \\
\text { core top was lost due } \\
\text { to blow-off on the drill } \\
\text { floor. Unconsolidated } \\
\text { silty clay with } \\
\text { pebbles. }\end{array}$ \\
\hline 3 & B & $\mathrm{P} / \mathrm{T}$ & 24.0 & 27.0 & 3.0 & 0.05 & 1.7 & 0.1 & $\begin{array}{l}\text { Failed to keep in situ } \\
\text { pressure due to leak. }\end{array}$ \\
\hline 4 & B & $\mathrm{H}$ & 50.0 & 59.0 & 9.0 & 9.75 & 108.3 & - & $\begin{array}{l}\text { Partial penetration. } \\
\text { Highly expanded and } \\
\text { blow-off from top and } \\
\text { bottom. Unconsoli- } \\
\text { dated silty clay with } \\
\text { pebbles. }\end{array}$ \\
\hline 5 & B & $\mathrm{P} / \mathrm{T}$ & 59.5 & 63.5 & 4.0 & 0.20 & 5.0 & 18 & $\begin{array}{l}\text { Succeeded in keeping } \\
\text { almost in situ pres- } \\
\text { sure. }\end{array}$ \\
\hline 6 & B & $\mathrm{H}$ & 100.0 & 105.5 & 5.5 & 6.10 & 110.9 & - & $\begin{array}{l}\text { Partial penetration. } \\
\text { Highly expanded and } \\
\text { blow-off from the bot- } \\
\text { tom. Unconsolidated } \\
\text { silty clay with } \\
\text { pebbles. }\end{array}$ \\
\hline 7 & B & $\mathrm{P} / \mathrm{X}$ & 109.5 & 113.5 & 4.0 & 0.20 & 5.0 & 0.4 & $\begin{array}{l}\text { Not sealed until near } \\
\text { the sea level. }\end{array}$ \\
\hline 8 & B & $\mathrm{H}$ & 113.5 & 122.1 & 8.6 & 9.14 & 106.3 & - & $\begin{array}{l}\text { Partial penetration. } \\
\text { Unconsolidated silty } \\
\text { clay with pebbles. }\end{array}$ \\
\hline 9 & B & $\mathrm{P} / \mathrm{X}$ & 190.0 & 194.0 & 4.0 & 0.00 & 0.0 & 16 & $\begin{array}{l}\text { Sealed, but no } \\
\text { recovery. }\end{array}$ \\
\hline 10 & B & $\mathrm{X}$ & 194.0 & 203.5 & 9.5 & 1.27 & 13.4 & - & $\begin{array}{l}\text { Plugged at CC. } \\
\text { Pebbly mudstone. }\end{array}$ \\
\hline 1 & $\mathrm{C}$ & $\mathrm{P} / \mathrm{X}$ & 0.0 & 6.5 & 6.5 & 0.90 & 13.8 & 23 & $\begin{array}{l}\text { Successfully sealed. } \\
\text { Recovered a short } \\
\text { but intact cylindrical } \\
\text { core. }\end{array}$ \\
\hline
\end{tabular}




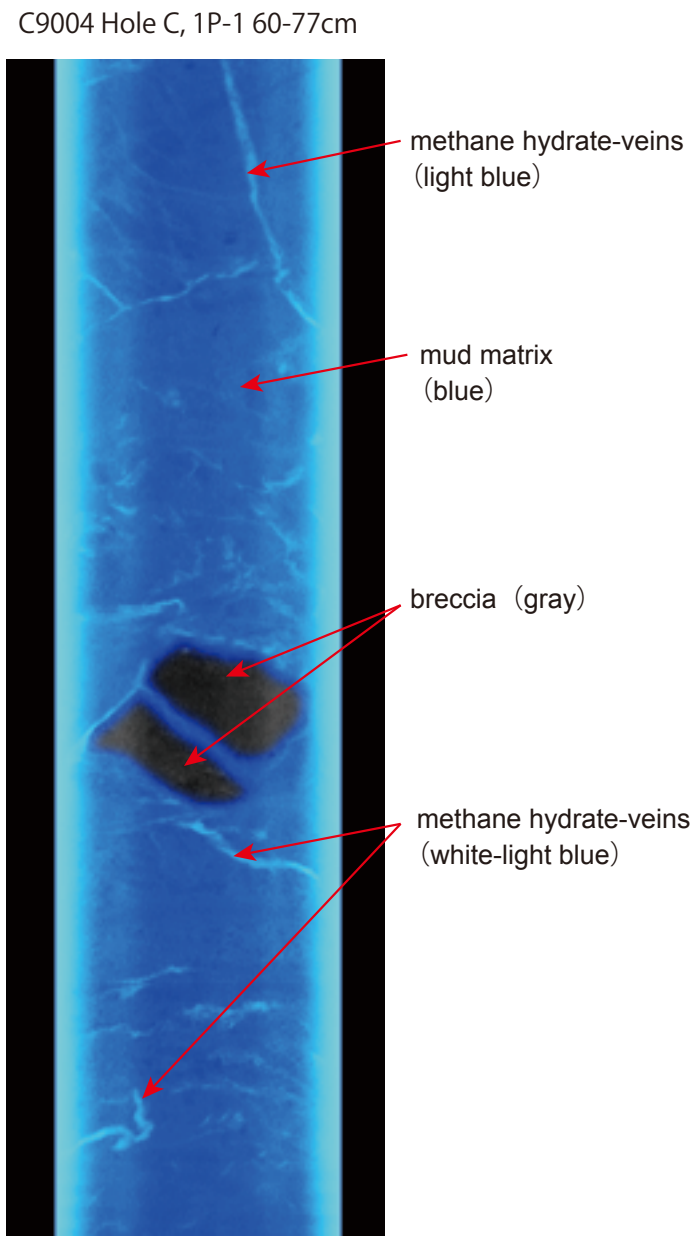

Figure 3. X-ray image of core C9004C-1P at full pressure in PCATS shows mud clast and methane hydrate veins in a matrix of hemipelagic mud.

onboard subsampling and geochemical analyses (e.g., isotopic measurements).

\section{Expedition 802}

The hybrid PCS was subsequently used in the following Chikyu expedition 802, which was a commercial drilling campaign operated by JOGMEC and Japan Petroleum Exploration Company (JAPEX) in July 2012. The coring operation applying hybrid PCS was carried out as part of the reservoir characterization effort for a planned gas production test from methane hydrates on the north slope of Daini Atumi Knoll in the eastern Nankai Trough (Yamamoto et al., 2012).

The core hole (AT1-C) was drilled in the vicinity of a previously drilled monitoring borehole (AT1-MC) in which intensive geophysical operations have been done by LWD (logging while drilling) and wireline tools in February 2012, enabling measured core properties to be compared with logged in situ values. The coring interval was selected to cover

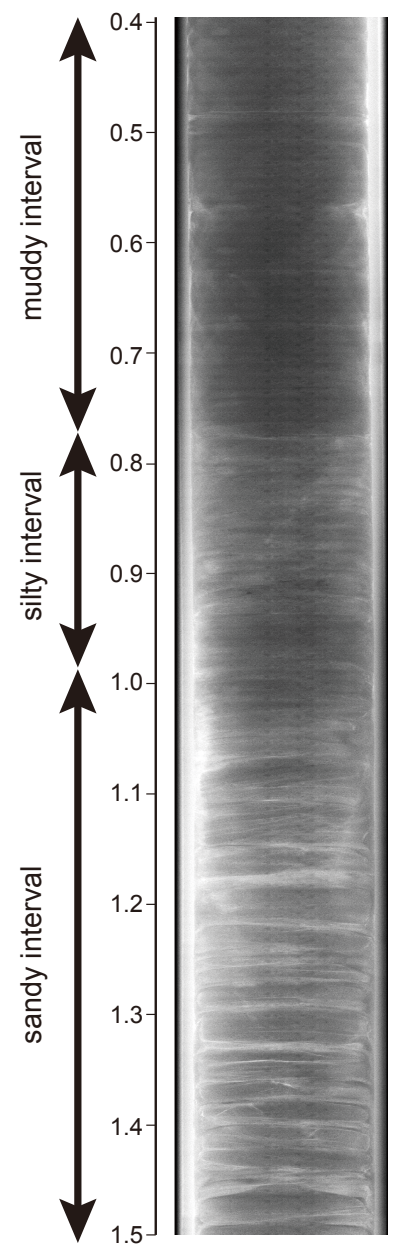

Figure 4. X-ray image of AT1-C-18P from expedition 802 shows clear image of lamina planes in turbidite structures. Sandy layers are highly saturated with methane hydrates. The image covers from 0.4 to $1.5 \mathrm{~m}$ of the core, and the diameter is $51 \mathrm{~mm}$.

around $45 \mathrm{~m}$ of methane hydrate-bearing sand-clay alternation layers and $15 \mathrm{~m}$ of overburden hemipelagic clay zone.

A total of 21 cores, including 18 pressure cores and 3 ESCS cores, were collected from the $60 \mathrm{~m}$ interval of the hole (262 to $322 \mathrm{mb}$ b.s.f.). The overall core recovery was $61 \%$, with $69 \%$ achieved with the hybrid PCS cores. CT observation showed that the structure of the sediments was well preserved, and detailed lamina structures of turbidite sediment were clearly observed, as shown in Fig. 4 . Of the 18 pressure cores taken, pressures $>12 \mathrm{MPa}$ were maintained in 8 cores (Table 3). According to gas release of some of the pressure core, high saturation of methane hydrate (up to about $70 \%$ fraction in pore space) was determined in some of the sandy intervals.

After the core recovery operation, the recovered cores were processed in three different schemes (Fig. 5). All of the Hybrid PCS cores were processed in PCATS with nondestructive analyses. The majority of well-pressure-preserved 
Table 3a. Coring summary of expedition 802 .

\begin{tabular}{|c|c|c|}
\hline Net coring time & \multicolumn{2}{|c|}{$17.5 \mathrm{~h}$} \\
\hline \multicolumn{3}{|l|}{ Number of cores } \\
\hline ESCS cores & \multicolumn{2}{|l|}{$3 \times 3 \mathrm{~m}$} \\
\hline Hybrid PCS cores & \multicolumn{2}{|c|}{$16 \times 3 \mathrm{~m}+2 \times 1.5 \mathrm{~m}$} \\
\hline \multicolumn{3}{|l|}{ Recovery rate } \\
\hline Entire interval & \multirow{2}{*}{\multicolumn{2}{|c|}{$\begin{array}{l}36.82 / 60 \mathrm{~m}, \\
\text { recovery rate } 61 \% \\
34.99 / 51 \mathrm{~m}, \\
\text { recovery rate } 69 \%\end{array}$}} \\
\hline Hybrid PCS & & \\
\hline \multicolumn{3}{|c|}{ Pressure condition } \\
\hline Pressure conserved cores $(>12 \mathrm{MPa})$ & 8 cores & $17.08 \mathrm{~m}$ \\
\hline $\begin{array}{l}\text { Partially pressure conserved cores } \\
(>5.5 \mathrm{MPa})\end{array}$ & 4 cores & $11.6 \mathrm{~m}$ \\
\hline Pressure lost $(<5.5 \mathrm{MPa})$ & 6 cores & $6.31 \mathrm{~m}$ \\
\hline
\end{tabular}

Table 3b. Place of analysis for pressurized and depressurized cores.

\begin{tabular}{lrl}
\hline Cores & Length & Place of analysis \\
\hline $\begin{array}{l}\text { ESCS cores } \\
\text { Depressurized cores }\end{array}$ & $12.83 \mathrm{~m}$ & $\begin{array}{l}\text { Chikyu laboratory } \\
\text { PCATS and Chikyu } \\
\text { laboratory }\end{array}$ \\
$\begin{array}{l}\text { Cores in pressure } \\
\text { chamber }\end{array}$ & $22.00 \mathrm{~m}$ & $\begin{array}{l}\text { PCCTs and AIST } \\
\text { laboratory (shore-based) }\end{array}$ \\
\hline
\end{tabular}

cores were stored in pressure vessels for future, more detailed analysis on shore. Some of the pressure cores were quickly cryo-frozen in liquid nitrogen to maintain gas hydrate stability. Such cores were used for measurement of petrophysical parameters in atmospheric pressure after surface conditioning. The remaining samples were treated following IODP protocols for geological description as well as geochemical/geotechnical and microbial analyses.

The samples were sent to onshore laboratories, including a facility of the National Agency for Advanced Industrial Science and Technology (AIST) in Sapporo equipped with a suite of core analysis devices for methane hydrate-bearing cores.

\section{Perspectives}

The hybrid PCS can be successfully deployed as a pressurecoring tool on the D/V Chikyu. It will be available for future scientific ocean drilling upon request from scientists, as well as for industrial operations that target hydrocarbon reservoirs such as natural gas accumulations and methane hydrates. With $3.5 \mathrm{~m}$ core length and $35 \mathrm{MPa}$ maximum pressure, the hybrid PCS will provide excellent performance. The recovery rate will be increased in future through tests of different cutting shoes. It is also desirable to increase the efficiency of

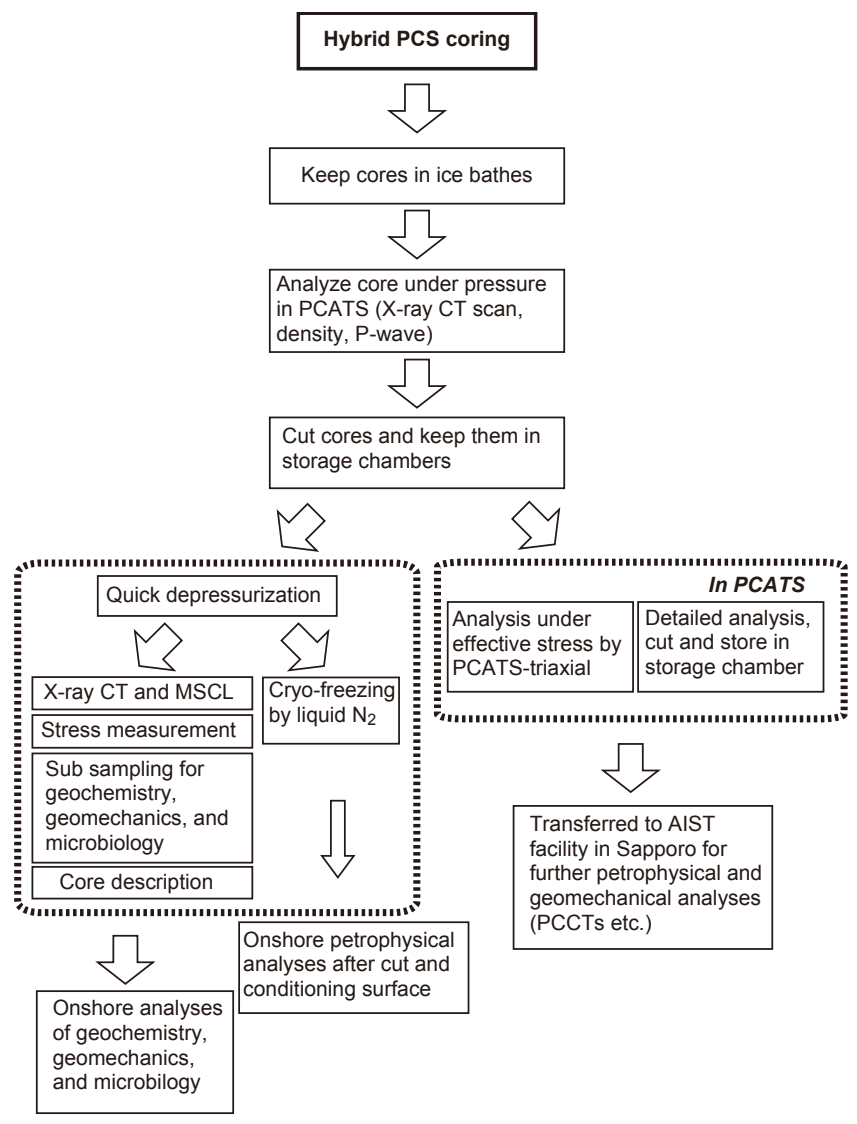

Figure 5. Schematic flow of the onboard core processing for Exp. 802. The obtained samples were processed in three different schemes. The majority of well-pressure-preserved cores were stored in pressure vessels for more detailed analysis on shore.

the onboard core transfer and subsampling under high pressure. These advancements will provide unprecedented opportunities to conduct geochemical, geophysical and biological analyses of gas hydrate-bearing sediment under in situ conditions. Use of the Hybrid PCS requires, on the other hand, careful planning for the operation and both onboard and onshore logistics. Potential users are therefore encouraged to contact CDEX at an early stage of proposal preparation.

Acknowledgements. The construction of the hybrid PCS for the D/V Chikyu was supported by the Strategic Fund for Strengthening Leading-Edge Research and Development (JAMSTEC) and the Funding Program for Next Generation World-Leading Researchers (NEXT Program, F. Inagaki) by the Japan Society for the Promotion of Science (JSPS) and the Ministry of Education, Culture, Sports, Science, and Technology (MEXT) of Japan. The authors are grateful to the ship crew, drilling staff and laboratory technicians of expeditions 906 and 802 for their dedication and assistance with all aspects of the onboard operations. PCATS was operated by the team of Geotek Ltd., UK. The hybrid PCS was designed by Aumann and Associates, Salt Lake City, Utah. J. Aumann's contributions to the project were invaluable. Pressure Core Characterization Tools 
(PCCTs) developed by the Georgia Institute of Technology (GIT) and the US Geological Survey were used for core analysis in AIST in January of 2013 under a collaboration project among AIST, GIT and JOGMEC. The authors would like to thank Peter Schultheiss and Kevin Grigar for their helpful and constructive comments on the manuscript.

Edited by: T. Wiersberg

Reviewed by: P. Schultheiss, K. Grigar, and J. Miller

\section{References}

Dickens, G. R., Paull, C. K., Wallace, P., and the ODP Leg 164 Scientific Party: Direct measurement of in situ methane quantities in a large gas-hydrate reservoir, Nature, 385, 426-428, 1997.

Dickens, G. R., Wallace, P. J., Paull, C. K., and Borowski, W. S.: Detection of methane gas hydrate in the pressure core sampler (PCS): volume-pressure-time relations during controlled degassing experiments, in: Proc. ODP, Sci. Results, 164, edited by: Paull, C. K., Matsumoto, R., Wallace, P. J., and Dillon, W. P., College Station, Texas (Ocean Drilling Program), 113-126, 2000.

Dickens, G. R., Schroeder, D., Hinrichs, K.-U., and the Leg 201 Scientific Party: The pressure core sampler (PCS) on ODP Leg 201: general operations and gas release, in: Proc. ODP, Init. Repts., edited by: D’Hondt, S. L., Jørgensen, B. B., Miller, D. J., et al., 201, 1-22, 2003.

Expedition 311 Scientists: Cascadia margin gas hydrates, IODP Prel. Rept., 311, doi:10.2204/iodp.pr.311.2005, 2005.

Fujii, T., Namikawa, T., Okui, T., Kawasaki, M., Ochiai, K., Nakamizui, M., Nishimura, M., Takano, O., and Tsuji, Y.: Methane-hydrate Occurrence and Saturation Confirmed from Core Samples, Eastern Nankai Trough, Japan, in: Natural Gas Hydrates-Energy Resource Potential and Associated Geologic Hazards. AAPG Memoir 89, edited by: Collett, T., Johnson, A., Knapp, C., and Boswell, R., 385-400, 2010.

Graber, K. K., Pollard, E., Jonasson, B., and Schulte, E.: Overview of ODP engineering tools and hardware. ODP Tech. Note 31, College Station, Texas (Ocean Drilling Program), 2002.
Kuramoto, S., Ashi, J., Greinert, J., Gulick, S., Ishimura, T., Morita, S., Nakamura, K., Okada, M., Okamoto, T., Rickert, D., Saito, S., Suess, E., Tsunogai, U., and Tomosugi, T.: Surface Observations of Subduction Related Mud Volcanoes and Large Thrust Sheets in the Nankai Subduction Margin; Report on YK00-10 and YK01-04 Cruises, JAMSTEC J. Deep Sea Res., 19, 131139, 2001.

Kvenvolden, K. A., Barnard, L. A., and Cameron, D. H.: Pressure core barrel: application to the study of gas hydrates, Deep Sea Drilling Project site 533, Leg 76, in: Init. Repts. DSDP 76, edited by: Sheridan, R. E., Gradstein, F. M., et al., U.S. Govt. Printing Office, Washington, D.C., 367-375, doi:10.2973/dsdp.proc.76.107.1983, 1983.

Paull, C. K., Lorenson, T. D., Dickens, G., Borowski, W. S., Ussler, W., and Kvenvolden, K.: Comparisons of In Situ and Core Gas Measurements in ODP Leg 164 Bore Holes, Annals of the New York Academy of Science, 912, 23-31, doi:10.1111/j.17496632.2000.tb06756.x, 2000.

Pettigrew, T. L.: Design and operation of a wireline pressure core sampler. ODP Tech. Note 17, Ocean Drilling Program, College Station, Texas, doi:10.2973/odp.tn.17.1992, 1992.

Schultheiss, P., Holland, M., and Humphrey, G.: Wireline Coring and Analysis under Pressure: Recent Use and Future Developments of the HYACINTH System, Sci. Drill., 7, 44-50, 2009.

Shipboard Scientific Party: Explanatory notes, in: Proc. ODP, Init. Repts., 204: College Station, TX (Ocean Drilling Program), edited by: Tréhu, A. M, Bohrmann, G., Rack, F. R., Torres, M. E., et al., 1-102, doi:10.2973/odp.proc.ir.204.102.2003, 2003.

Tsunogai, U., Maegawa, K., Sato, S., Komatsu, D., Nakagawa, F., Toki, T., and Ashi, J.: Coseimic massive methane release from a submarine mud volcano, Earth Planet. Sc. Lett., 341-344, 79-85, 2012.

Yamamoto, K., Inada, N., Kubo, S., Fujii, T., Suzuki, K., Konno, Y., and shipboard scientists for the methane hydrate offshore production test: Pressure core sampling in the Eastern Nankai Trough, Fire in the ice, 12, 1-6, 2012. 